Check for updates

Cite this: RSC Adv., 2022, 12, 5280

\title{
Correction: Synthesis and stereocomplex formation of enantiomeric alternating copolymers with two types of chiral centers, poly(lactic acid- alt-2-hydroxybutanoic acid)s
}

\author{
Hideto Tsuji, ${ }^{*}$ Kazuya Nakayama and Yuki Arakawa
}

DOI: $10.1039 / \mathrm{d} 2 \mathrm{ra} 90003 \mathrm{c}$

rsc.li/rsc-advances

Correction for 'Synthesis and stereocomplex formation of enantiomeric alternating copolymers with two types of chiral centers, poly(lactic acid-alt-2-hydroxybutanoic acid)s' by Hideto Tsuji et al., RSC Adv., 2020, 10, 39000-39007. DOI: 10.1039/DORA08351H.

In the original manuscript, incorrect weight- and number-average molecular weights ( $M_{\mathrm{w}}$ and $M_{\mathrm{n}}$, respectively) were shown for the synthesized and used polymers in the 2 . Experimental section. The correct $M_{\mathrm{w}}$ and $M_{\mathrm{n}}$ values of P(LLA-alt-L-2HB) and P(DLA-alt-D$2 \mathrm{HB}$ ) were $3.00 \times 10^{4}, 3.08 \times 10^{4}, 1.53 \times 10^{4}$, and $1.54 \times 10^{4} \mathrm{~g} \mathrm{~mol}^{-1}$, respectively.

Due to the correction of the molecular weight values, the authors would like to remove the following statement regarding the suggested reason for the noncrystallizability of unblended P(LLA-alt-L-2HB) and P(DLA-alt-D-2HB) in the 3.2. Wide-angle X-ray diffractometry section based on the low molecular weight values: "The noncrystallizability of $\mathrm{P}(\mathrm{LLA}-$ alt-L-2HB) and $\mathrm{P}(\mathrm{DLA}-$ alt-D$2 \mathrm{HB})$ may be due to their lower $M_{\mathrm{w}}$ values $\left(M_{\mathrm{w}}=3.0 \times 10^{3}\right.$ and $3.1 \times 10^{3}, \mathrm{~g} \mathrm{~mol}{ }^{-1}$, respectively) compared to those of the P(LLA-co-L2HB) (56/44) and P(DLA-co-D-2HB) (52/48) random copolymers $\left(M_{\mathrm{w}}=1.4 \times 10^{4}\right.$ and $1.6 \times 10^{4}$, g mol ${ }^{-1}$, respectively) and P(LLA-altGA) and P(DLA-alt-GA) alternating copolymers $\left(M_{\mathrm{w}}=4.8 \times 10^{3}\right.$ and $5.9 \times 10^{3}, \mathrm{~g} \mathrm{~mol}^{-1}$, respectively).”.

Due to the same reason, in the 3.3. Differential scanning calorimetry section, the authors would like to remove the statement "The lower $T_{\mathrm{m}}$ values of $\mathrm{P}(\mathrm{LLA}-$ alt-L-2HB) and $\mathrm{P}(\mathrm{DLA}-$ alt-D-2HB) can be attributable to the low molecular weights compared to those of PLLA and PDLA, P(LLA-co-L-2HB) (56/44) and P(DLA-co-D-2HB) (52/48), and P(LLA-alt-GA) and P(DLA-alt-GA).”. Additionally, the authors would like to replace the statement "The $T_{\mathrm{m}}$ values for $\mathrm{P}(\mathrm{LLA}-$ alt-L-2HB$) / \mathrm{P}(\mathrm{DLA}-$ alt-D-2HB $)\left(M_{\mathrm{w}}=3.0 \times 10^{3}\right.$ and $3.1 \times 10^{3}$, $\mathrm{g}$ $\mathrm{mol}^{-1}$, respectively) blends are higher than those for solvent-evaporated and melt-crystallized $\left(T_{\mathrm{c}}=70^{\circ} \mathrm{C}\right) \mathrm{P}(\mathrm{L}-2 \mathrm{HB}) / \mathrm{P}(\mathrm{D}-2 \mathrm{HB})\left(M_{\mathrm{w}}=\right.$ $1.8 \times 10^{3}$ and $3.3 \times 10^{3}, \mathrm{~g} \mathrm{~mol}^{-1}$, respectively) homopolymer blends $\left(T_{\mathrm{m}}=173.0 \text { and } 172.1^{\circ} \mathrm{C} \text {, respectively }\right)^{81}$ but lower than those for melt-crystallized $\left(T_{\mathrm{c}}=130{ }^{\circ} \mathrm{C}\right)$ PLLA/PDLA $\left(M_{\mathrm{w}}=4.0 \times 10^{3}\right.$ and $5.4 \times 10^{3}, \mathrm{~g} \mathrm{~mol}^{-1}$, respectively) homopolymer blends $\left(T_{\mathrm{m}}=\right.$ $\left.197.5^{\circ} \mathrm{C}\right),{ }^{78}$ and solvent-evaporated and melt-crystallized $\left(T_{\mathrm{c}}=160{ }^{\circ} \mathrm{C}\right) \mathrm{P}(\mathrm{LLA}-\mathrm{co}-\mathrm{L}-2 \mathrm{HB})(56 / 44) / \mathrm{P}(\mathrm{DLA}-\mathrm{co}-\mathrm{D}-2 \mathrm{HB})(52 / 48)\left(M_{\mathrm{w}}=1.4\right.$ $\times 10^{4}$ and $1.6 \times 10^{4}, \mathrm{~g} \mathrm{~mol}^{-1}$, respectively) random copolymer blends (203.6 and $\left.198.4^{\circ} \mathrm{C}\right){ }^{63}$ and solvent evaporated and meltcrystallized $\left(T_{\mathrm{c}}=100^{\circ} \mathrm{C}\right) \mathrm{P}($ LLA-alt-GA $) / \mathrm{P}(\mathrm{DLA}-$ alt-GA $)\left(M_{\mathrm{w}}=4.8 \times 10^{3}\right.$ and $5.9 \times 10^{3}$, $\mathrm{g}$ mol $^{-1}$, respectively $)$ blends $(187.8$ and $\left.187.6^{\circ} \mathrm{C}\right) .{ }^{67}$ " with the revised statement "The $T_{\mathrm{m}}$ values for $\mathrm{P}(\mathrm{LLA}-$ alt $-\mathrm{L}-2 \mathrm{HB}) / \mathrm{P}(\mathrm{DLA}-$ alt $-\mathrm{D}-2 \mathrm{HB})\left(M_{\mathrm{w}}=3.0 \times 10^{4}\right.$ and $3.1 \times 10^{4} \mathrm{~g}$ $\mathrm{mol}^{-1}$, respectively) blends are lower than those for solvent-evaporated and melt-crystallized $\left(T_{\mathrm{c}}=70^{\circ} \mathrm{C}\right) \mathrm{P}(\mathrm{L}-2 \mathrm{HB}) / \mathrm{P}(\mathrm{D}-2 \mathrm{HB})\left(M_{\mathrm{w}}=\right.$ $3.1 \times 10^{4}$ and $3.3 \times 10^{4} \mathrm{~g} \mathrm{~mol}^{-1}$, respectively) homopolymer blends $\left(T_{\mathrm{m}}=218.9\right.$ and $214.5^{\circ} \mathrm{C}$, respectively ${ }^{81}$ and those for meltcrystallized $\left(T_{\mathrm{c}}=130^{\circ} \mathrm{C}\right)$ PLLA/PDLA $\left(M_{\mathrm{w}}=4.0 \times 10^{3}\right.$ and $5.4 \times 10^{3} \mathrm{~g} \mathrm{~mol}^{-1}$, respectively $)$ homopolymer blends $\left(T_{\mathrm{m}}=197.5{ }^{\circ} \mathrm{C}\right),{ }^{78}$ and solvent-evaporated and melt-crystallized $\left(T_{\mathrm{c}}=160^{\circ} \mathrm{C}\right) \mathrm{P}(\mathrm{LLA}-\mathrm{co}-\mathrm{L}-2 \mathrm{HB})(56 / 44) / \mathrm{P}(\mathrm{DLA}-\mathrm{co}-\mathrm{D}-2 \mathrm{HB})(52 / 48)\left(M_{\mathrm{w}}=1.4 \times 10^{4}\right.$ and 1.6 $\times 10^{4} \mathrm{~g} \mathrm{~mol}^{-1}$, respectively) random copolymer blends $\left(203.6 \text { and } 198.4{ }^{\circ} \mathrm{C}\right)^{63}$, but similar to those of solvent evaporated and meltcrystallized $\left(T_{\mathrm{c}}=100^{\circ} \mathrm{C}\right) \mathrm{P}($ LLA-alt-GA $) / \mathrm{P}(\mathrm{DLA}-$ alt-GA $)\left(M_{\mathrm{w}}=4.8 \times 10^{3}\right.$ and $5.9 \times 10^{3} \mathrm{~g} \mathrm{~mol}^{-1}$, respectively) blends $(187.8$ and 187.6 $\left.{ }^{\circ} \mathrm{C}\right) .{ }^{67}$ ".

The Royal Society of Chemistry apologises for these errors and any consequent inconvenience to authors and readers. 